\title{
Earnings Management And Initial Public Offerings: An Empirical Analysis
}

\author{
Tarek Miloud, Inseec Alpes-Savoie Business School, France
}

\begin{abstract}
This paper studies the presence of earnings management in initial public offerings (IPOs) of French firms. When the aim of earnings management is to increase the attractiveness of the offered shares it needs to go undetected by market participants. This invisibility makes earnings management difficult to detect in the income statement and the balance sheet, thus investors would benefit from other information that reveals the probability of earnings management. Managers' and owners' incentives for managing earnings are used to assess the likelihood that earnings management is used before the IPO. Earnings management is tested by observing time-series profiles of accruals. The sample consists of French firms that went public in the years 1995 to 2008 on the Euronext Paris Exchange. The results suggest that IPO firms with the highest discretionary current accruals significantly underperformed, compared to equivalent companies in the third year following the IPOs.
\end{abstract}

Keywords: Earnings Management; IPO; Accruals; Ownership Structure

\section{INTRODUCTION}

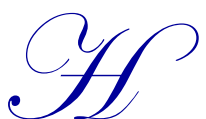

ealy and Wahlen (1999) define earnings management as an activity where managers use judgment to alter financial reports, either to mislead stakeholders or to influence contractual outcomes. Compared to bad accounting or simple randomness, the distinguishing feature of earnings management is the presence of intent. Before a typical initial public offering (IPO), managers possess a combination of incentives and possibilities to manage earnings. More and more literature has documented the presence of earnings management in IPO firms. It suggests that the differences that are remarked in opportunistic behavior are the result of managers' incentives for managing earnings and their possibilities to do it without detection.

Friedlan (1994) reports show that IPO issuers make income-increasing discretionary accruals in the financial statements released before the offering. This evidence is consistent with the hypothesis that issuers believe that financial statement information affects IPO offering prices. Moreover, according to Teoh et al. (1998c) these accruals tend to reverse in later reporting periods. They also found that abnormal accruals during the year of IPOs are significantly negatively related to post-offer stock returns. Furthermore, Aharony, Lee and Wong (2000) identified evidence of earnings manipulation among listed firms prior to their IPOs. Moreover, DuCharme, Malatesta and Sefcik (2004) show that abnormal accruals around IPOs are negatively related to post-offer returns and positively related to initial firm value. Indeed, Xie (2001) reports that abnormal accruals are negatively correlated with subsequent stock returns in the firms. Therefore, the relationship between abnormal accruals and post-offer stock returns appears to be part of a more general empirical regularity. Chen and Yuan (2004) found that listed firms manage earnings to satisfy the ROE requirements for rights issues, and argue that such earnings management behavior is associated with mis-allocation of capital resources. Chen, Firth, Gao and Rui (2006) found that various aspects of corporate governance (e.g., the characteristics of boards of directors and ownership) are associated with the incidence of corporate financial fraud.

These results raise serious questions regarding market efficiency with respect to widely available accounting information. They are consistent with the interpretation that IPOs firms opportunistically manage earnings upward around IPO dates, temporarily inflating their stock prices, which later fall as less favorable earnings 
information arrives after the offer. The main task of this paper is to examine whether the ownership type of the IPO firms is associated with their propensity for earnings management behavior. Furthermore, this paper is related to the previous studies investigating and predicting the performance of IPO firms (e.g. Brav \& Gompers, 1997; Hensler, Rutherford \& Springer, 1997; Jain \& Kini, 2000; Bhabra \& Pettway, 2003; Bessler \& Thies, 2007). We purpose in this paper to demonstrate that French IPO Companies practice "earnings management," so the main research questions and some of the findings, can be summarized as:

- Why? What are the motivations to "manage" earnings? We present some evidence that French companies (US firms), manage their numbers to: (i) avoid losses, (ii) sustain recent performance, (iii) guarantee income "smoothing" and (iv) satisfy debt covenants.

- How? How earnings are "managed"? It will be shown that earnings are managed by discretionary adjustment (discretionary accruals), as well by as non-operational accounts.

- What are effects? What are the consequences of this opportunistic behavior? Does it incur costs to stakeholders? Does Earnings management influence the Stock price? We observed that companies, on average, in the short run can "fool" the market by implementing practices of "earnings management", but in the long run they will underperform. These results have important implications to reflect about the correct allocation of capital.

In the rest of the paper, we will present a brief summary of previous related empirical research designs on the topic of earnings management. The theoretical framework on earnings management around IPOs and the hypotheses are presented in the third section. In the following we will present our sample and methodologies, whereas the empirical analysis is mentioned in Section 5. Section 6 concludes the paper.

\section{THEORY AND LITERATURE REVUE}

\subsection{Definitions and Main Empirical Results on the Earnings Management}

Mulford and Comiskey (2005) argue that earnings are considered as the most vital indicators of accounting numbers; thus, all types of accounting manipulations are concerned with company earnings. Creative accounting, aggressive accounting, big bath accounting, the street earnings or window dressing, all refer to earnings management. Tirole (2006) admits that earnings management is a means used by the management to modify the external assessment of the firm's performance. Yet, definitions radically oppose each other when describing goals and effects of earnings management. Dechow and Skinner (2000) and Scott (2011) argue that earnings management is a way, for the management, to share private information on the future prospects of the company, which is beneficial to investors. Schrand and Zechman (2012) suggest that earnings management is like a "slippery slope to fraud."

But probably the most popular and extensive definition in the literature remains the one given by Healy and Wahlen (1999) (p. 368): Earnings management "occurs when managers use judgment in financial reporting and in structuring transactions to alter financial reports to either mislead some stakeholders about the underlying economic performance of the company, or to influence contractual outcomes that depend on reported accounting numbers." These definitions lead to argue that earnings management is the choice by a manager of accounting policies, or other actions including voluntary earnings forecasting, voluntary disclosure, and estimation of accruals, to intentionally affect the earnings. Most studies in the earnings management literature have focused on three research designs: (i) based on aggregate accruals; (ii) based on specific accruals and (iii) based on the distribution of earnings.

\subsubsection{Aggregate Accrual Models}

Testing the earnings management requires to measure management's discretion over earnings. Hence, the discretionary accrual model helps the researcher to split total accruals into discretionary accruals and nondiscretionary components. The discretionary accruals can raise/reduce the net income, without any link to any operational activity of the company. They are positive or negative exclusively at the discretion of the management. When the manager raises/reduces accruals at his discretion, he has to reverse the effect; this fact is explained by the double-entry bookkeeping. To face this problem, Healy (1985) and Deangelo (1986) used total accruals and 
changes in total accrual as proxies of discretion of earnings management. Jones (1991) introduced a regression approach to control non-discretionary factors that can influence accruals specifying a linear relation between total accrual and changes in sales and property, plant and equipment.

The Jones' model assumes that non-discretionary accruals depend on the change in revenues and the level of property, plant and equipment. The rationale is that firms' working capital requirements depend on sales, while its depreciation depends on the level of property. Once the model is estimated (either in time-series or crosssectional), the researcher uses forecasted values to estimate non-discretionary accrual. With this model any accrual not treated as non-discretionary is included as discretionary accruals. Most of the critics to Jones model are based in the misclassification problem, which reduces the power of the test. In the best scenario, lower the power of the research design, but in a worst situation, can cause the researcher to conclude that there is earnings management when none actually exists. Comparing five commonly used models of discretionary accrual, Dechow et al. (1995) conclude that the modified version of the Jones model offer the best results. However, the authors recognize that none of these models offers a really powerful method. So it may be that the "state of art" is not very satisfying.

\subsubsection{Specific Accruals}

The second approach in the literature is to model a specific accrual as Mchichols and Wilson (1988), Petroni (1992), Beaver and McNichols (1998). They focus on industry settings in which a single accrual requires substantial judgment. The authors concentrate on more specific industries or in the analysis of specific accruals, where modeling opportunities are richer, even though this model can be applied only in a very limited number of firms, due to a lack of specific data which are not always available. This model is applied to analyze financial institution, and in general to demonstrate earnings management.

\subsubsection{Frequency Distribution Approach}

Burgstaler and Dichev (1997) and Degeroge, Patel and Zeckhaiser (1999) develop a third approach by examining the statistical properties of earnings to identify behavior that influences earnings management. These works focus on the behavior of earnings around a specific benchmark, such as zero or a prior quarter earnings, to test whether the incidence of amounts above and below the benchmark. Furthermore, they test whether the incidence of amounts above and below the benchmarks are distributed smoothly or reflect discontinuities due to exercise of discretion. Compared to other methods, the most important advantage of this approach is not necessary to estimate the discretionary accruals. Furthermore, this approach can help to have an idea of how many firms use this kind of instrument to proportionate earnings management. Nevertheless, this method has some disadvantages, for instance, it neither captures the magnitude of earnings management, nor identifies which method is used to manage earnings.

\subsection{Earnings Management through Real Activities Manipulations}

We have seen that earnings management is a decision taken by the manager with a direct impact on cash flow. Dechow and Skinner (2000), Healy and Wahlen (1999) and Fudenberg and Tirole (1995) identified the companies that seem to engage in the following activities: [i] decreasing the expenses in R\&D, [ii] decreasing of general and administrative expenses, [iii] the timing of sales by offering discounts or providing more flexible credit terms and [iv] the excess production. As with the studies of Durtschi and Easton (2005) and Burgstaler and Dichev (1997) assume that the discontinuities observed in the distribution of the earnings are real actions taken by management. They authors observe an increase in operating cash flow nearby zero thresholds. However, their findings are statistical non-significance test.

According to some researchers, such as Beneish (2001), the earnings management is often difficult to detect. Relying on Schipper (1989) work, they predict that it is difficult to distinguish between optimal management decision and willingness to manipulate accounting figures. It is only recently that researchers (Lambert \& Sponem, 2005; Graham et al., 2005) based on qualitative studies are then oriented modeling of real earnings management and that distinguishing the discretionary portion of the non-discretionary variable to handle. Roychowdhury (2006) works made several contributions which are summarized as follows: 
- $\quad$ in methodological terms: from the study of Dechow, Kothari and Watts (1998), the authors develop a model to measure normal levels of cash flow from operations, production costs and discretionary spending (R \& D, general, administrative, and advertising expenses). These variables should capture the effect of actual actions better than accruals.

- $\quad$ in the academic field: the author enriches the literature on earnings management by proving that U.S. companies handle their real activities to achieve the zero threshold.

For their part, Eldenburg et al. (2011) reported that hospital CEOs in California manage real activities of their companies either up or down depending on the intended purposes during the year. They found that hospitals with slightly negative earnings reduce their spending for some ineffective activities such as general expenses, research expenses and administrative expenses to prevent the publication of losses, while hospitals with slightly positive earnings decrease asset sales and are rarely audited. Herrmann, Inoue and Thomas (2003), meanwhile, showed that Japanese companies increased their results through action on their sales when the current operating results downfall related to management forecasts, and vice versa. Thomas and Zhang (2002) report that the negative accrual-return relation is mainly due to inventory changes, and interpret this evidence as investors not recognizing the temporary nature of growth.

Finally, to examine the key factors that motivate the managers of U.S. companies to undertake certain operational decisions, such as reducing discretionary spending, Graham et al. (2005) conducted a survey with 401 Chief Financial Officers and detailed interviews with 20 CEOs. They observed that interviewers reveal their willingness to engage in the real earnings management better than to engage in the management of accruals. This motivation is preferred especially in cases where the real earnings management activities cannot be differentiated optimal economic decisions, and thus be hardly detected. According to this literature review, we point out that:

- $\quad$ only one study in the French context has examined the phenomenon of real earnings management. However, most of these works were done in the U.S. context.

- $\quad$ managers engage earnings management by acting on the following real activities: R \& D, sales, production, general, administrative, and advertising expenses.

Figure 1 summarizes the main empirical studies on the two strategies of earnings management, namely: the accounting earnings and the real earnings management. 


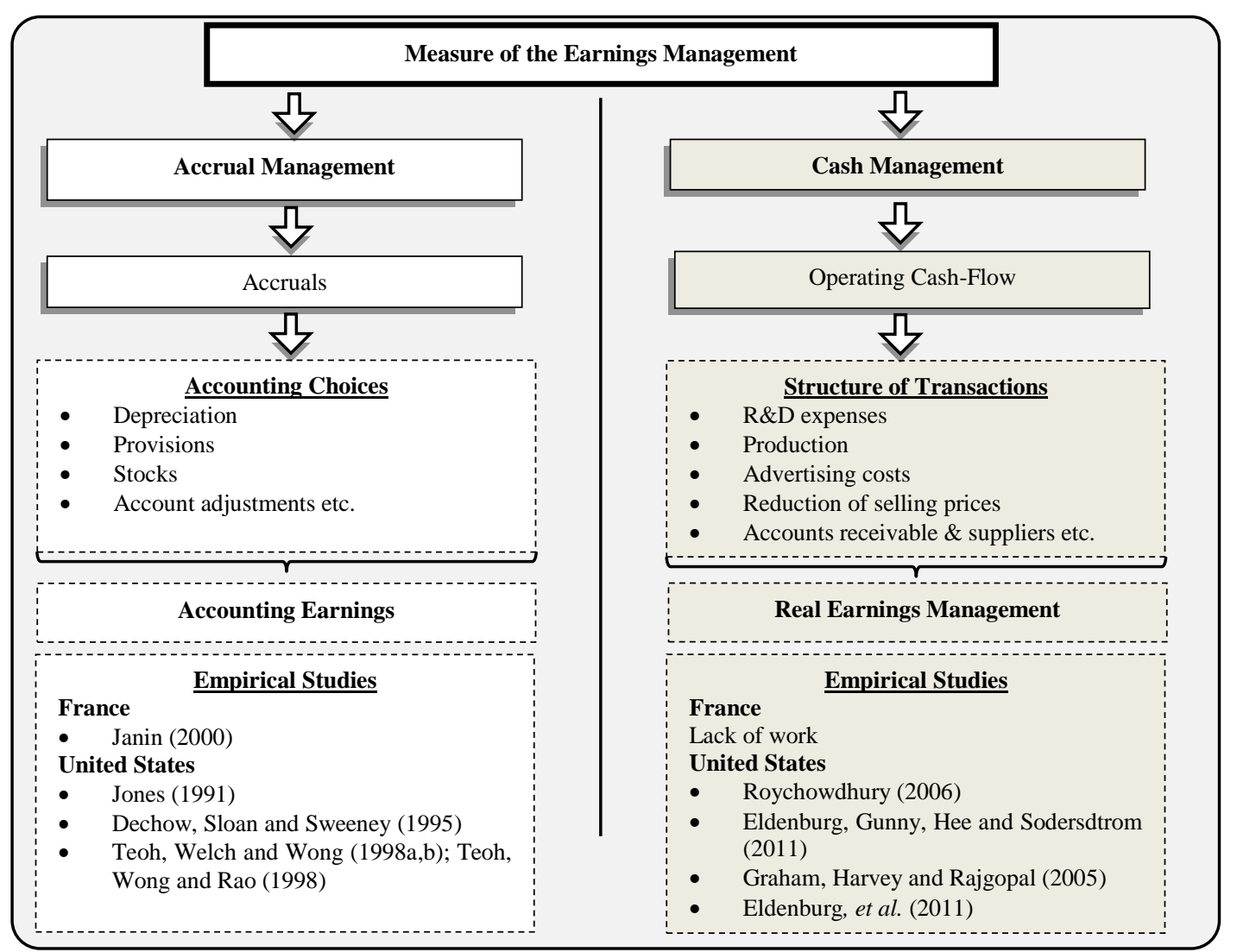

Figure 1: Accrual Management and Earnings Management in the Literature

\subsection{Detecting Earnings through Discretionary Accruals}

How can we measure earnings management? It is not possible to observe earnings management directly. Therefore, researchers have investigated two venues for earnings management, the choice of accounting methods and the management of accruals. The most commonly used method for testing earnings management is the examination of accruals because they are easier to manipulate than cash flows. Abnormal accruals (Abnormal accruals $=$ Total Accruals - Normal Accruals) are considered as a sign of earnings management. The major problem in earnings management studies is how to determine if accruals are abnormally high or low. Most models used to estimate the normal level of accruals base their estimations on the firms' past accruals or the accruals of comparable firms. In the literature the normal and abnormal accruals are usually called nondiscretionary and discretionary accruals. From the literature, we observe that past research in their attempt to study accruals use two models: Healy (1985) and Deangelo (1986) who use total accruals as a proxy for earnings management while Jones (1991) and Teoh et al. (1998a,b) who use discretionary accruals as a measure of earnings management. One possible explanation to exclude non-discretionary accruals is that they are used to reflect the economic conditions which are not controlled by managers. Discretionary accruals represent managerial interventions into financial reporting process. Accruals include all adjustments that allow a business to change from a cash basis to an accrual basis - whether this means allocations, provisions or changes in accounting methods. Changes in working capital also form part of accruals. The following equation shows the calculation:

\section{Total accruals $=$ earnings - cash flow (from operations)}

The trick for researchers is to identify the discretionary component of accruals: non-discretionary and discretionary components of accruals cannot be directly observed, so it is necessary to develop methods for estimating the discretionary accruals. What researchers want to know can be shown as:

Discretionary accruals + Non-discretionary accruals = Earnings - Cash Flow (from operations) 
Researchers have developed several techniques to estimate discretionary accruals. One approach uses total accruals as an estimate of discretionary accruals and looks for earnings management by comparing the amount of accruals in different firms. A second method examines differences in accruals between periods. For example, a researcher might either assume that non-discretionary accruals do not change between periods and attribute differences in total accruals to management discretion, or, the researcher might adjust the estimate of nondiscretionary accruals to reflect economic changes such as growth. A third approach uses regression techniques to separate the discretionary and non-discretionary components of accruals. The most popular discretionary model is the standard Jones (1991) model. This model is able to decompose accruals into discretionary and non-discretionary accruals. When changes in sales are adjusted for the change in receivables, standard Jones model becomes a modified Jones model, which is proposed by Dechow et al. (1995). The modified model is designed to reduce the measurement error of discretionary accruals when discretion is applied over sale. The study by Dechow et al. (1995) finds that a modified Jones model provides the most powerful test of earnings management compared to the standard Jones industry model. However, Yoon and Miller (2002) document that the Modified Jones model is not effective in measuring discretionary accruals for Korean firms.

Unlike the study of Dechow et al. (1995), Guay, Kothari and Watts (1996) conclude that both the Jones and modified Jones models provide reliable estimates of discretionary accruals. Peasnell, Pope and Young (2000) find that Jones and modified Jones models are able to generate powerful tests for earnings management and are more powerful for the revenue and bad debt manipulations than non-bad debt manipulations. In tests comparing the power of the modified-Jones model with that of the standard Jones model, Dechow et al. (1995) find that the first procedure is indeed significantly better at detecting sales-based earnings management. Previous research examines the specification and power of various discretionary-accrual models, but not that of performance-matched accrual models. Dechow et al. (1995) (p. 193) conclude: "all models reject the null hypothesis of no earnings management at rates exceeding the specified test levels when applied to samples of firms with extreme financial performance." Guay et al. (1996) explain that firms with extreme performance are more likely to engage in earnings management and that discretionary accrual models correctly detect it as such. Alternatively, the discretionary accrual models might be misspecified when applied to samples of firms with extreme performances, in part because performance and estimated discretionary accruals exhibit a mechanical relation. To the extent that the concern is model misspecification, and because earnings management research typically examines non-random samples (e.g., samples that firms self-select into by, for example, changing auditors), earnings management studies must employ means of mitigating the misspecification to reduce the likelihood of incorrect inferences. In this vein, the use of a control sample to address specification issues is common in the literature.

\section{EARNINGS MANAGEMENT PRIOR TO IPOS AND ITS EFFECT ON FIRM PERFORMANCE}

Neill, Pourciau and Schaefer (1995) report that, proceeds from the IPO using income-increasing (liberal), for example borrowing aggressively from future earnings, are relatively higher than those using income-decreasing (conservative) methods when analyzing accounting method choice. Thus, there is incentive for issuing firms to manage earnings to raise enough capital when the investors foresee the share price to increase. In addition, managers can personally earn abnormal profits when they sell their own shares.

Managers attempt to manipulate earnings in order to influence short-term stock price performance and also for job security. However, according to Abdullah, Espenlaubb and Strongb (2009), aggressive management of earnings through income-increasing accounting adjustments leads investors to be overly optimistic about the issuer's prospect and thus overvalues the new issues. When these high pre-issue earnings are not sustained over time, disappointed investors will subsequently underprice the firm. Inevitably, according to Rangan (1998), managers will continue to manage earnings in the subsequent two quarters after the offering announcement for two reasons: (i) an earnings reversal immediately after the offering and the associated price drop could invite lawsuits against the firm and its manager; (ii) firms enter into lock-up agreements with their underwriters that prevent their insiders from selling their holdings until 90 to 180 days after the offering date.

\subsection{Earnings Management in IPOs}

Before firms go public, there is no market value for reference. The major purpose of firms making IPOs is to raise cash. Thus, firms have strong incentives to manage earnings. Firms with better figures in financial 
reporting have the opportunity to set higher offering prices. Such incentive also plays an active role when firms are to issue seasoned equity offerings (SEO), since firms also make SEO to raise cash. On a voluntary disclosure basis, Clarkson, Dontoh, Richardson and Sefcik (1992) empirically tested the hypothesis that earnings forecasts communicate firms' prospectuses. They found evidence that the Canadian market positively responds to such earnings forecasts that conveys good news.

Many past literatures such as Loughran and Ritter (1997), Rangan (1998) and Teoh et al. (1998a) provide evidence that CEOs manage earnings during IPOs in the US market. These studies report that earnings management during IPOs causes poor long run stock performance. During IPO, reported earnings are high due to high discretionary accruals component. There is a negative relation between discretionary accruals and post-offering abnormal stock returns. The high discretionary accruals tend to predict worse stock price performance. Stock price under-perform, as investors are disappointed with subsequent earnings decline. Teoh et al. (1998a) in their hypothesis predict worse performance for issuers with usually large income-increasing accounting adjustments prior to the offering. Their interesting research reveals that issuers in the most 'aggressive' quartile underperform the matched non-issuers by $7.5 \%$ in the three years following the issue year and also they underperform conservative issuers. In contrast, issuers conservatively outperform their match.

Pre-offering shareholders of issuing firms benefit from misevaluations of share prices that are caused by earnings management. Rangan (1998) also provides evidence to reject the notion that issuing firms are simply timing their offerings after quarters of high earnings and are not manipulating earnings, and that at least a portion of the discretionary accruals represents deliberate earnings management. Rangan's study differs from Loughran and Ritter (1997) and Teoh et al. (1998a) to short term stock returns following the offering year and not long-term performance. According to Shivakumar (2000), managers of offering firms manipulate earnings not to influence investor valuations but as a rational response to the expected negative market reaction at the announcement. As expected with discretionary accruals, the general pattern of pre-issue earnings management, for instance higher discretionary accrual quartile, shows better pre-issue earnings performance than the lower discretionary current accruals and cannot predict post-issue stock return under performance.

Other studies have examined earnings reporting around IPOs of common stock. Among others, Teoh et al. (1998b), Yoon and Miller (2002) and Abdullah et al. (2009) all report empirical evidence that suggests earnings are managed in anticipation of going public. It is unclear if the measures of earnings management employed in this research can truly reflect the deceptive nature of manipulation of revenues and expenses intended to enhance reported earnings (and, thereby, IPO proceeds), or reflective of normal operating, investing and financing decisions of IPO firms. It is difficult to distinguish legitimate earnings reporting from subtly misleading practices, and there is no generally accepted method of doing so. If it's costly for management to mislead investors, then discretionary accounting choices might be focused on increasing the information content of reported earnings. Ritter (1991) provides empirical evidence that IPO firms' stock returns are significantly lower than those of a matched sample of non-IPO firms over the three-year period after offering. He concluded that "investors are periodically overoptimistic about the earnings potential of young growth companies." Following Ritter's (1991) view, it may be likely that such long-run market underperformance of IPOs is not about investors' misperception of the firms' future potential, but rather a result of earnings management during the process of firms going public. His study implies that entrepreneurs mislead investors by manipulating earnings and investors react negatively. This finding is further supported by Jain and Kini (1994) who examine accounting measures of operating performance of IPO firms. They find that firms exhibit a decline in operating performance after their IPOs as a result of not being able to further borrow from future high expectations of future earnings growth that are not subsequently fulfilled.

Teoh et al. (1998b) also investigate earnings management during the year of IPO and subsequent stock returns. They find a significant negative association between abnormal accruals measured during the year of offer and stock returns over a three-year post IPO period. Teoh et al. (1998b) report issuers with unusual high accruals in the IPO year experience poor stock return performance in the three following years. IPO issuers in the most 'aggressive' quartile of earnings' managers have a three-year aftermarket stock return of approximately $20 \%$ less than IPO issuers in the most 'conservative' quartile. According to DuCharme et al. (2004), pre-IPO abnormal accruals are positively related to initial firm value. Their results also confirm the earlier studies: abnormal accruals 
during the offer year are significantly negatively related to subsequent form stock returns. In addition, they also find that abnormal accruals in the previous year are also significantly negatively related to subsequent performance.

\subsection{Discretionary Accruals in IPO}

The research based on U.S. data provides strong evidence of discretionary accruals in IPO firms. Friedlan (1994) found that firms manage earnings upwards to get higher offer prices prior to IPO through income-increasing accruals that affect the offering price. Teoh et al. (1998a) found that firms with abnormally high accruals before the IPO experience poor market performance of their stock returns in the following three years. Along a similar line to the earnings management of IPOs, Teoh et al. (1998c) document a negative relation between pre-issue discretionary accruals and post-issue earnings and stock returns that suggests firms also manage earnings by means of discretionary current accruals before making SEOs.

Additionally, Teoh et al. (1998a) showed that discretionary accruals can be linked to companies' long term stock market performance and thus challenged the efficient market hypothesis, that the market fails to take into account the probability of manipulation into account. When they grouped firms by their amount of discretionary accruals before the IPO, they found that firms in the quartile with the lowest discretionary accruals (negative) outperformed the market by about $4 \%$ over three years, whereas firms in the quartile with the highest discretionary accruals underperformed the market by about $25 \%$.

Furthermore, Aharony et al. (2000) identified evidence of earnings manipulation among listed firms prior to their IPOS. Moreover, DuCharme et al. (2004) showed that abnormal accruals around IPOs are negatively related to post-offer returns and positively related to initial firm value. In fact, Xie (2001) reports that abnormal accruals are negatively correlated with subsequent stock returns in the firms. Therefore, the relationship between abnormal accruals and post-offer stock returns appears to be part of a more general empirical regularity. Chen and Yuan (2004) found that listed firms manage earnings to satisfy the ROE requirements for rights issues, and argue that such earnings management behavior is associated with the misallocation of capital resources.

Darrough and Rangan (2005) found that in addition to the discretionary current accruals, managers also manipulate R\&D spending to increase the IPO offer price. Chen et al. (2006) found that various aspects of corporate governance (e.g., boardroom characteristics and ownership) are associated with the incidence of corporate financial fraud.

\subsection{Hypothesis Development}

\subsubsection{Ownership Structure and Earnings Management}

Previous studies brought evidence that ownership structures influence the monitoring mechanism a company uses, including the monitoring of earnings management activities. Wang (2006) stated that ownership structures have important effects on reported earnings. However, the influence of insiders, institutional investors, and block-holders on the ability of managers to manipulate earnings remains a controversial issue. Morck, Shleifer and Vishny (1988) argued that greater ownership would provide managers with deeper entrenchment and, therefore, greater scope for opportunistic behavior.

The literature discriminates between inside and outside holders. For example, Dempsey, Hunt and Schroeder (1993) distinguished between owner-managed firms, in which managers own substantial blocks of the firms' outstanding stocks, and external-controlled-firms, in which one or more external block-holders own a substantial block of the firm's stocks while the managers do not substantially own the firm's stocks. The authors suggested that large ownership by management is the underlying factor that reduces earnings management, whereas the existence of external block-holders does not seem to significantly affect earnings management. In addition,Warfield, Wild and Wild (1995) provide evidence that managerial ownership is negatively related to the size of earnings management. Warfield et al. (1995) also found evidence that the inverse relationship between managerial ownership and absolute abnormal accruals becomes moderated in the case of regulated firms. They suggest that the regulations lead to monitoring of the managers' choices for making accrual adjustments to manage earnings. 
The manner in which earnings management is associated with institutional ownership is an empirical issue. Existing literature posits two competing views on institutional investors. The first group of literature such as that of Wahal and McConnell (2000) and Velury and Jenkins (2006) among many others, provides evidence indicating that institutions are playing an active role in monitoring and disciplining managerial discretion. The second group of studies such as those of Porter (1992), Bushee (1998) and Grace and Koh (2005) alleges that frequent trading and fragmented ownership discourage institutions from becoming actively involved in the corporate governance of their portfolio firms. Koh (2007) extended the literature by classifying institutional investors into transient or long-term ones according to their investment horizons in order to examine the association between an institutional investor type and firms' discretionary earnings management strategies in two mutually exclusive settings - firms that (do not) use accruals to meet/beat earnings targets. The results support the view that long-term institutional investors constrain accruals management among firms that manage earnings to meet/beat earnings benchmarks. This suggests long-term institutional investors can mitigate aggressive earnings management among these firms. Transient institutional ownership is not systematically associated with aggressive earnings management and is evident only among firms that manage earnings to meet/beat their earnings benchmarks.

Sánchez-Ballesta and García-Meca (2007) examined the relationship between ownership structure and discretionary accruals for a sample of Spanish non-financial companies. Their results support the hypothesis that insider ownership contributes to the constraining of earnings management when the proportion of shares held by insiders is not too high. However, when insiders own a large percentage of the shares, they are entrenched and the relation between insider ownership and discretionary accruals reverses. Gabrielsen, Gramlich and Plenborg (2002) found a positive, but non-significant relationship between managerial ownership and discretionary accruals in a sample of Danish firms, which they attributed to the different institutional settings between the US and Denmark. To date, only one study was conducted on earnings management in French IPOs. In addition to showing that earnings management was present in French IPOs, Cormier and Martinez (2006) investigated whether there was any difference in earnings management behavior in IPOs from 2000 and 2002. The study investigated managers' motivations to engage in earnings management through purposeful interventions in the setting of discretionary accruals during the IPO process. The results indicated that earnings management is influenced by a firm's contractual and governance constraints. The above arguments conform to the following testable hypotheses:

Hypothesis (1): French IPO companies exhibit non-zero earnings management in the IPO year.

Hypothesis (2): Earnings management by French IPO companies is related to pre-IPO owners' level of post-IPO retained ownership.

\subsubsection{Earnings Management and the Long-Term Performance}

An excellent review of IPO studies by Ritter and Welch (2002) reveals the existence of severe aftermarket underperformance for issuers. This phenomenon was been reported in the U.S. and in other countries. Teoh et al. (1998 a,b) and DuCharme et al. (2004) provide evidence that earnings management can at least in part explain the aftermarket performance of public equity issues. Chou, Gombola and Liu (2006) investigated whether the earnings management explanation for the long-term stock performance of public issues also holds for equity private issues. Their results suggest that Discretionary Current Accruals (DCA) predict the cross-sectional variation in post-IPO long-term stock return performance. 'Aggressive' earnings management companies, with higher income-increasing accruals in the IPO year, experience poorer stock return performance in the 3 post-IPO years than 'conservative' earnings management companies. They argued that investors are misled by the high earnings numbers reported at the time of IPOs and so put too high a price on the new issues. Roosenboom, van der Goot and Mertens (2003) found a similar negative relationship between the size of the DCA in the IPO year and stock returns over the following 3 years. This negative relationship between earnings management and subsequent stock return performance is used to arguing that opportunistic IPO earnings management has the potential to (at least partially) explain the long-term stock market return underperformance of IPOs. We reexamined this hypothesis for our IPO French sample. This paper is one of the few studies available that examines IPOs in France. These observations and arguments lead to our third hypothesis:

Hypothesis (3): Higher income-increasing earnings management by French IPO companies shows a poorer longterm stock return performance than by more 'conservative' counterparts. 


\section{DATA SAMPLE AND RESEARCH DESIGN}

\subsection{Sample Selection and Data}

To test our hypotheses, we have compiled a list of all IPOs that were floated on the Paris Stock Exchange ${ }^{1}$ from January 1, 1995 to December 31, 2008. From the original list of 806 IPOs, we excluded readmissions and transfers from the main market to the official market, flotations of units, and investment trusts. We excluded all IPOs that represented demergers, corporate spin-offs, reverse takeovers, and equity reorganizations, whose board development processes differ from founder-involved IPOs. We also excluded investment and acquisition vehicles because their governance systems were extremely simplified and their boards resembled investment committees of private equity firms. These processes of elimination excluded 238 observations.

The final sample included 568 IPOs from 1995 to 2008. Data was collected from the information provided in the IPO listing prospectuses and annual reports. Stock returns and financial data come from Datastream. The accrual variables for measuring discretionary current accruals during the IPO year (year 0) were hand-collected from the first post-IPO published annual reports, which included the financial information for both pre- and post-IPO years. Consistent with Teoh et al. (1998a), the first published annual reports after the IPO were used due to incomplete data in the prospectus financial statements.

\subsection{Measuring the Level of Earnings Management}

Chou et al. (2006) noted that earnings management can be accomplished through recognition of revenues or delaying recognition of expenses relative to cash flows. It can also be accomplished through changes in accounting methods and in capital structure. Differences between revenues recognized and cash received, or between expenses recognized and cash expenditures create accruals or deferrals. Since the basis of earnings management lies in the difference between cash flows and earnings, analyzing accruals, which is the difference between cash flows and earnings, provides insight into earnings management practices.

Not all accrual items are equally subject to manipulation or management. Long-term accrual and deferral items, which are accounting adjustments to long-term assets or liabilities, such as depreciation, are difficult to manage or adjust since accounting choices for long-term assets remain consistent over several years. Short-term accruals, which are accounting adjustments to short term assets, such as the change in accounts receivable, are easier to manage since accounting choices are made over a shorter term. Because short-term accruals are more easily subject to management, the focus of our study, like that of similar studies, is on short-term accruals. Computation of accruals in our study is based on definitions of accruals by Perry and Williams (1994) that were also used by Teoh et al. (1998a,b). Perry and Williams (1994) compute total accruals as the change in non-cash working capital (excluding current maturities of long-term debt less total depreciation expense for the current period). Their definition is similar to Jones (1991), differing by the exclusion of the adjustment she made for income taxes. Perry and Williams (1994) included income tax in their model because income tax accrual can be an important component of an earnings management strategy.

Earnings management is revealed by an abnormal level of accruals relative to the firm's business activity. In the same way as Teoh et al. (1998a,b) and DuCharme et al. (2004), a regression model has been used to estimate the expected accruals. Deviations from the expected accruals could be subject to management discretion and could be attributed to earning management. Teoh et al. $(1998 \mathrm{a}, \mathrm{b})$ call these deviations discretionary current accruals.

We followed the methodology of Teoh et al. (1998a,b) to estimate the expected current accruals by a modification of the Jones (1991) model. Expected accruals, called nondiscretionary current accruals by Teoh et al. (1998a, 1998b), are estimated from a cross-sectional regression of current accruals in a given year on the change in sales using an estimation sample that includes all firms with the same two-digit SIC code as the private equity issuer, but excludes the issuer and other private equity issuers. To ensure that the estimated coefficients obtained

\footnotetext{
${ }^{1}$ Now known as the NYSE Euronext $(N Y X)$ with the merger of equals between the leading U.S. and pan-European securities trading exchanges the holding company of the New York Stock Exchange and Euronext N.V, the Paris-based first European integrated stock exchange was formed in September 2000 by the merger of the Paris, Brussels, and Amsterdam exchanges.
} 
from the regression are not biased, the number of two-digit SIC code peers is required to be at least 30 . To reduce heteroskedasticity in the data, we scaled all variables in the regression by total assets. We ran the following crosssectional regression using the estimation sample:

$C A_{j, t} / T A_{j, t-1}=\alpha_{0}\left(1 / T A_{j, t-1}\right)+\alpha_{1}\left(\Delta\right.$ Sales $\left._{j, t} / T A_{j, t-1}\right)+\varepsilon_{j, t}$

where $C A$ is current accruals, $T A$ is total assets, $\triangle$ Sales is the change in sales, $j$ is firm $j$ in the estimation sample, and $t$ indicates year $t$. Nondiscretionary (or expected) current accruals for private placement firm $i$, is estimated as:

$N D C A_{i, t}=\widehat{\alpha_{0}} \times\left(\frac{1}{T A_{j, t-1}}\right)+\widehat{\alpha_{1}} \times\left[\frac{\left(\Delta \text { Sales }_{i, t}-\Delta T R_{i}\right)}{T A_{j, t-1}}\right]$

where $\widehat{\alpha}_{0}$ is the estimated intercept, $\widehat{\alpha}_{1}$ is the slope coefficient for private placement firm, $i$, and $\Delta T R_{i, t}$ is the change in trade receivables for year $t$ for private placement firm $i$. The increase in trade receivables is subtracted from the change in sales to allow, for the possibility of credit sales manipulation by the issuer.

Discretionary current accruals, $D C A_{i, t}$, for private placement firm $i$ for year $t$ is then estimated as:

$D C A_{i, t}=C A_{i, t} / T A_{i, t-1}-N D C A_{i, t}$

\subsection{Empirical Methods}

To investigate patterns of DCA in the years following the IPO and the influence of economic conditions, we conducted a univariate analysis. Then, we use a multivariate specification to investigate different hypotheses, while checking for additional factors that may influence earnings management. The level of IPO-year earnings management is regressed on experimental variables relating to the level of retained share ownership and to several additional control variables: auditor reputation, underwriter prestige, company age, size of underpricing, the degree of leverage, company size, and the board of listing. The estimated regression model is:

$D C A Y R_{0, i}=\alpha_{0}+\beta_{1} \operatorname{RetO} w n+\beta_{2}$ AauditR $+\beta_{3}$ Under $W+\beta_{4} \log (1+I P O$ Age $)+\beta_{5}$ Underpricing + $\beta_{6} \operatorname{Lev}+\beta_{7} \ln M V+\varepsilon_{i}$

where:

- $\quad D C A Y R_{0}=$ IPO year discretionary current accruals as a percentage of lagged total assets

- $\quad$ RetOwn = percentage of shares retained by insiders (original owners) after the IPO

- $\quad$ Audit $R=$ dummy variable $=1$ if auditor is Big 5 (Arthur Andersen, Deloitte, Ernst and Young, KPMG, Price Waterhouse Coopers, or their pre-merger equivalents), and 0 otherwise

- $\quad U n d e r W=$ dummy variable $=1$ for prestigious underwriter, and 0 otherwise

- $\quad \lg A g e=\log (1+I P O A g e):$ Age $=$ company age in years

- $\quad$ Underpricing $=$ adjusted initial return $(\%)$ measured by comparing the share price $\left(P_{t}\right)$ at the end of the first day of trading with the offer price $\left(P_{0}\right):\left[\left(P_{t}-P_{0}\right) / P_{0}\right]-\left[\left(\right.\right.$ Index $_{t}-$ Index $\left._{0}\right) /$ Index $\left._{0}\right]$

- $\quad L E V=$ financial leverage ratio (debt-to-equity ratio), at the time of the IPO

- $\ln M V=$ natural $\log$ of the market value at the time of the IPO computed as the number of shares outstanding times the closing price on the first trading day

- $\quad \varepsilon_{i}=$ error term

Significance levels are computed as White's t-statistics to correct for heteroskedasticity.

\subsection{Measure of Long-Term Stock Market Performance}

Fama (1998) indicated that long-term returns are sensitive to the expected return model used to measure the abnormal returns and the statistical tests conducted. The author points out that the buy-and-hold abnormal return 
method can be problematic because the long-term buy-and-hold returns distribution is skewed. Additionally, stock returns of firms announcing a specific corporate event are usually correlated, as pointed out by Fama (1998), Lyon, Barber and Tsai (1999), among others. Mitchell and Stafford (2000) showed that the cross-dependence problem of overlapping event-firm stock returns can inflate t-statistics of BHAR. To address the cross-sectional dependence problem, we have used the monthly calendar-time portfolio approach, recommended by Fama (1998) and Mitchell and Stafford (2000), to estimate both of the three-factor models. Portfolios of private placements are formed monthly, in calendar time. The regression model is:

$R_{p, t}-R_{f t}=\alpha_{p}+\beta_{p}\left(R_{m t}-R_{f t}\right)+s_{p} S M B_{t}+h_{p} H M L_{t}+\varepsilon_{p, t}$

where $R_{p, t}$ is the return on portfolio $p$ in month $t, R_{f t}$ is the return on the Treasury bills (BTF, Bons du Trésor à court terme) in month $t, R_{m t}$ is the return on a market index in month $t, S M B_{t}$ is the difference in the returns of a portfolio of small and large stocks in month $t$, and $H M L_{t}$ is the difference in the returns of a portfolio of high book-to-market stocks and low book-to-market stocks in month $t$, and $\varepsilon_{p, t}$ is the error term for portfolio $p$ in month $t$. The estimate of the intercept coefficient $\left(\alpha_{p}\right)$ provides a test of the null hypothesis of zero average abnormal return.

\section{EMPIRICAL RESULTS}

\subsection{Descriptive Statistics}

Table 1 presents descriptive statistics for the full sample of 568 French IPOs. Mean (Median) Market value for our sample is $€ 975.36$ million ( $€ 280.20$ million). Operating performance prior to the IPO, measured by operating income by sales (OI/Sales), is about $18 \%$.

Table 1: Descriptive Statistics for 568 French IPOs between 1995 and 2008

\begin{tabular}{lcccc}
\hline & Mean & Median & Minimum & Maximum \\
\hline Market value at flotation (M€) & 975.36 & 31.99 & 402 & 121,563 \\
Sales (M€) & 280.20 & 13.79 & 225 & 17,143 \\
Total assets (M\$) & 564.34 & 164.9 & 27.23 & 40,872 \\
Leverage (\%): Total debt/equity & 25.12 & 19.44 & 9.65 & 85,20 \\
Operating income/Sales (\%) & 18.53 & 15.85 & -2.76 & 68.34 \\
Age & 9.97 & 8.45 & 0.93 & 34 \\
Underpricing (\%) & 16.48 & 12.26 & -35.56 & 156 \\
Retained ownership (\%) & 65.56 & 67.80 & 32.50 & 73.25 \\
Auditor - prestigious (\%) & 71.60 & & & \\
Underwriter - prestigious & 68.45 & & & \\
DCA in IPO year (\%) & $2,78^{* * *}$ & $2,28^{* * *}$ & -15.32 & 25.45 \\
\hline
\end{tabular}

*,**, and *** represent statistical significance at the $10 \%, 5 \%$, and $1 \%$ levels, respectively.

The average age of French IPOs is 10 years, slightly higher than 9 years for the US companies as mentioned by Teoh et al. (1998b), but considerably lower than the 35 years for Dutch companies as reported by Roosenboom et al. (2003). The mean (Median) level of underpricing is 25\%, which is higher than the $18.4 \%$ level in U.S markets mentioned by Ibbotson, Sindelar and Ritter (1988) but lower than the $27.7 \%$ German level proved by Ljungqvist (1997). The mean retained ownership by the original owners is broadly similar to $65.56 \%$ reported by Jain and Kini (1994). Over $71 \%$ of the IPO companies choose Big 5 auditors and more than $68 \%$ choose prestigious underwriters.

\subsection{Univariate Analysis}

We test the first hypothesis using univariate analysis, Table 2 reports the median and the mean of discretionary current accruals (DCA) estimated by the modified Jones (1991) model, for the 3 years before and after the IPO. The median DCA for the issue year is $2.3 \%$ which declined to $0.5 \%$ in the year following the IPO (year + 1 ), to $-0.8 \%$ (year +2 ) and to $-0.3 \%$ (year +3 ). The result for year 0 and +1 are statistically significant at $5 \%$ and $10 \%$, respectively. 
Table 2: Discretionary Current Accruals for IPOs between 1995 and 2008

\begin{tabular}{lccccccc}
\hline \multicolumn{1}{c}{ Year } & $\mathbf{- 3}$ & $\mathbf{- 2}$ & $\mathbf{- 1}$ & $\mathbf{0}($ Issue year) & $\mathbf{+ 1}$ & $\mathbf{+ 2}$ & $\mathbf{+ 3}$ \\
\hline Median & -0.002 & 0.008 & -0.012 & 0.023 & 0.005 & -0.008 & -0.003 \\
p-value (Wilcoxon) & $(0.06)$ & $(0.51)$ & $(0.75)$ & $(2.52)$ & $(0.89)$ & $(0.18)$ & $(0.04)$ \\
Mean & 0.086 & -0.050 & -0.601 & 0.028 & -0.480 & -0.200 & 0.087 \\
p-value (t-test) & $(0.43)$ & $(0.36)$ & $(0.28)$ & $(2.34)$ & $(0.67)$ & $(0.71)$ & $(0.39)$ \\
\hline
\end{tabular}

In the first year after the IPO, the median DCA of $0.5 \%$ remains income-increasing, which suggests that French IPO companies continue to manage their earning upward after the IPO. We saw some evidence that accruals reverse 2 years after the IPO year, the same result was observed for the United States markets by Teoh et al. (1998a).

\subsection{Multivariate Analysis}

Table 3 presents results for the OLS multivariate regression, used for testing the second hypothesis. The percentage of shares retained by the original owners has a positive relationship to earnings management and is statistically significant at $1 \%$. Owners who maintain a low (high) proportion of stakes in the capital post-IPO engage less (more) in income-increasing earnings management. This result contradicts the notion that owners maximize their short-term wealth by using income-increasing accruals to elevate the IPO price. Similarly, the positive relationship between retained ownership and DCA is inconsistent with a characterization where owners of high-quality companies signal quality by underpricing shares sold at the IPO (potentially using income-reducing accruals).

Table 3: Determinants of Earnings Management for 568 French IPOs between 1995 and 2008

\begin{tabular}{|c|c|c|}
\hline Variables & Coefficient & t-stat \\
\hline Constant & -19.06 & $-2.75^{* * * *}$ \\
\hline $\operatorname{RetOwn}$ & 0.438 & $3.15^{* * * *}$ \\
\hline AauditR & -5.76 & $-2.74^{* * *}$ \\
\hline UnderW & -1.44 & -0.86 \\
\hline $\log (1+I P O A g e)$ & 0.98 & $-1.70^{*}$ \\
\hline Underpricing & 0.010 & 0.64 \\
\hline Lev & -0.122 & -1.37 \\
\hline $\ln M V$ & 2.38 & 1.45 \\
\hline$n$ & 568 & \\
\hline Adjusted $R^{2}$ & 0.103 & \\
\hline$F$ & $3.90^{* * * *}$ & \\
\hline
\end{tabular}

The positive relation between DCA and retained ownership is consistent with incentives and aforementioned arguments. Hence, original owners who sell a relatively large proportion of their ownership interest apparently forego the increase in immediate wealth that might accrue from a higher offer price as a result of incomeincreasing earnings management. This leads the original ownership to ensure a high level of underpricing to oversubscription to the offer, thereby enabling shares to be allocated to many small investors. According to Brennan and Franks (1997), this reduces the threat of takeover and monitoring by large block-holders. Our results are consistent with those of Alavi, Pham and Pham (2008), who find that managers are reluctant to allocate shares to large new shareholders when control retention is an important consideration. There is strong evidence of a positive relationship between retained share ownership and income-increasing earnings management, consistent with the notion that post-IPO control may be more important than short-term wealth gains.

The coefficient for auditor' reputation is statistically significant at $1 \%$, this implies that companies audited by Big 5 auditors reduce the level of income-increasing earnings management, consistent with Chen et al. (2006). This suggests that either high-quality auditors are more likely to detect or deter earnings management, or managers of high-quality IPOs, with a reduced need to manage earnings, signal the quality by appointing high-quality auditors. The firm age is significant and negatively correlated to the earnings management. This suggests less uncertainty about the value of an IPO for a company with a longer operating history, thereby reducing the need or the opportunity to use income-increase DCA to manage earnings at the IPO time. This is significant for the underwriter 
reputation, underpricing, company size and the leverage level. The insignificance of the underpricing variable suggests that DCA are not related to the first day returns. We can affirm that earnings management is generally not undertaken for short-term opportunistic reasons in Euronext-NYSE Paris. Our results contrast with those of Aharony et al. (2000), who found that earnings management is more pronounced for smaller companies and for those with large financial leverage.

\subsection{Earnings Management and Post-IPO Stock Market Performance}

In this section, we have examined the monthly abnormal returns (MARs) estimated from the three-factor model of Fama and French (1993). As mentioned previously, calendar-time portfolios represent an important improvement over the traditional event methodology, which assumes independence of individual-firm abnormal returns. Table 4 reports the three-factor time series regression results for the three years following the issue. The intercept from the Fama and French (1993) three factors model regression is negative $(-1.26 \%$ and $-1.28 \%)$ and significant ( $\mathrm{t}$-statistic $=-2.09$ and -2.15 ). The significantly positive $H M L$ and $S M B$ loadings means that the French IPOs examined are small and value stocks; this confirms our previous observations.

Table 4: Calendar-Time Three-Factor Model for the Sample of IPOs from 1995-2008

\begin{tabular}{|c|c|c|c|c|c|c|}
\hline & \multicolumn{2}{|c|}{$(0,+12$ month $)$} & \multicolumn{2}{|c|}{$(0,+24$ month $)$} & \multicolumn{2}{|c|}{$(0,+36$ month $)$} \\
\hline & $\begin{array}{c}\text { Value- } \\
\text { Weighted }\end{array}$ & $\begin{array}{c}\text { Equal- } \\
\text { Weighted }\end{array}$ & $\begin{array}{c}\text { Value- } \\
\text { Weighted }\end{array}$ & $\begin{array}{c}\text { Equal- } \\
\text { Weighted }\end{array}$ & $\begin{array}{c}\text { Value- } \\
\text { Weighted }\end{array}$ & $\begin{array}{c}\text { Equal- } \\
\text { Weighted }\end{array}$ \\
\hline$\alpha$ & $\begin{array}{c}-0.0136^{* *} \\
(-2.13)\end{array}$ & $\begin{array}{c}-0.022^{* *} \\
(-2.31)\end{array}$ & $\begin{array}{c}-0.0132^{* *} \\
(-2.29)\end{array}$ & $\begin{array}{c}-0.0138^{* *} \\
(-2.45)\end{array}$ & $\begin{array}{c}-0.0126^{* *} \\
(-2.09)\end{array}$ & $\begin{array}{c}-0.0128^{* *} \\
(-2.15)\end{array}$ \\
\hline$\beta$ & $\begin{array}{c}1.148^{* * * *} \\
(7.57)\end{array}$ & $\begin{array}{c}1.136^{* * *} \\
(8.32)\end{array}$ & $\begin{array}{c}1.121^{* * * *} \\
(4.46)\end{array}$ & $\begin{array}{c}1.121^{* * * *} \\
(4.46)\end{array}$ & $\begin{array}{c}1.011^{* * *} \\
(2.24)\end{array}$ & $\begin{array}{l}1.441^{* * *} \\
(2.29)\end{array}$ \\
\hline$s$ & $\begin{array}{l}0.781^{* * * *} \\
(2.87)\end{array}$ & $\begin{array}{c}1.366^{* * *} \\
(3.24)\end{array}$ & $\begin{array}{l}0.940^{* * * *} \\
(2.63)\end{array}$ & $\begin{array}{l}1.409^{* * *} \\
(2.78)\end{array}$ & $\begin{array}{l}1.276^{* * *} \\
(2.38)\end{array}$ & $\begin{array}{l}1.540^{* * *} \\
(2.34)\end{array}$ \\
\hline$h$ & $\begin{array}{c}-0.489^{* * *} \\
(-4.67)\end{array}$ & $\begin{array}{c}-0.306^{* * *} \\
(-3.08)\end{array}$ & $\begin{array}{c}-0.502^{* * *} \\
(-5.09)\end{array}$ & $\begin{array}{c}-0.620^{* * * *} \\
(-4.90)\end{array}$ & $\begin{array}{c}-0.417^{* * * *} \\
(-4.21)\end{array}$ & $\begin{array}{c}-0.571^{* * * *} \\
(-5.21)\end{array}$ \\
\hline Adjusted $R^{2}$ & 0.1625 & 0.1562 & 0.1786 & 0.1680 & 0.1303 & 0.1450 \\
\hline
\end{tabular}

${ }^{*},{ }^{* *}$, and $^{* * * *}$ represent statistical significance at the $10 \%, 5 \%$, and $1 \%$ levels, respectively.

Table 5 contains post-issue average abnormal returns for DCA quartiles of IPO firms, relative to the threefactor model of Fama and French (1993). As shown in the table, there was significant underperformance only for firms in the most aggressive quartile (i.e., the quartile with the highest DCA). For the study period, the estimated alpha coefficient (i.e., average MAE) is -0.0174 , which is significant at the 0.01 level $(t=-3.43)$. This MAR implies a three-year abnormal return of -54.1\%. The estimated alpha coefficients shown for Quartiles 2, 3, and 4 are negative, but not significant for all cases. A monotonic relation between the DCA quartile and the estimated alpha coefficient is not evident in the results shown in Table 5. Consequently, there is little evidence of a negative relation between DCA and post-issue stock returns apart from evidence of the worst stock performance being indicated for the most aggressive DCA quartile.

The difference between stock performance for the most aggressive DCA quartile and other quartiles is substantial. For example, the implied three-year abnormal return for the most aggressive quartile is $-54.1 \%$, much worse than the implied three-year abnormal returns of $-8.3 \%,-25.4 \%$, and $-6.6 \%$ for Quartiles 2, 3, and 4, respectively. The abnormal return for the most aggressive quartile is less than the abnormal return for other quartiles by at least $28 \%$ and as much as $48 \%$ for three years.

Table 5: MARs and Three-Year ARs Relative to 3-Factor Model for DCA Quartiles

\begin{tabular}{|c|c|c|c|c|}
\hline & Quartile 1 & Quartile 2 & Quartile 3 & Quartile 4 \\
\hline Alpha coefficient & -0.0174 & -0.0024 & -0.0081 & -0.0019 \\
\hline WLS t-stat. & $(-3.43)^{* * *}$ & $(-0.38)$ & $(-1.23)$ & $(-0.25)$ \\
\hline Implied 3-vear abnormal returns & $-54.1 \%$ & $-8.3 \%$ & $-25.4 \%$ & $-6.6 \%$ \\
\hline
\end{tabular}

The regression coefficients reported in the table are estimated using weighted least squares for value-weighted portfolios. The implied three-year abnormal returns are estimated as: $(1+\text { alpha coefficient })^{36}-1 .{ }^{*},{ }^{* *}$, and ${ }^{* * *}$ represent statistical significance at the $10 \%, 5 \%$, and $1 \%$ levels, respectively. 
Overall, results shown in Table 5 show substantial evidence of underperformance for firms that practice aggressive earnings management at the time of an IPO. The evidence is robust and consistent for the two time periods examined and a variety of return measures and benchmarks were used. The results suggest that underperformance following an IPO is caused by the poor stock price performance of firms practicing aggressive earnings management. These results also indicate that any investor's optimism about prospects of private equity issuing firms might be at least partially the result of aggressive earnings management on the part of a minority of firms.

\section{CONCLUSIONS}

The purpose of our research focuses on the question of earnings management in the French IPOs. More specifically, our work examines how managers' and owners' incentives for managing earnings are used to assess the likelihood that earnings management is used before the IPO. Earnings management is tested by observing timeseries profiles of accruals using a sample of 866 observations between 1995 and 2008 . This paper is the first detailed, large sample study of the long term operating performance and earnings management of French IPO companies.

The main results of this study can be summarized as follows. First, the comparison of pre-and post-IPO accounting-based operating performance in terms of levels and changes provides several interesting findings. Second, there is moderate evidence supporting the view that the average IPO company in France underperforms benchmark companies over the three year post-IPO period. However, there is strong evidence of declining performance in the IPO year and up to three years following the IPO. Third, the year-to-year analysis reveals that decline in performance is greater in the year immediately following the IPO. This finding is consistent with the results of prior studies documenting the long term underperformance of IPOs. Results also confirm that the deterioration in the post-IPO operating performance is due to earnings management by IPO managers at the time of going public.

Analysis of the results leads us to verify that the French companies manage their sales to reach a few planned objectives during the fiscal year. This confirms the commitment of managers to engage in real earnings management while acting on the sales of the year. However, our findings need to be interpreted with some reserves since, as any research work, this study has limits. First, our research does not provide a more detailed list of all the activities that can be used by managers during a potential real earnings management activity. A more complete discussion of other types of real activities is left for future research, such as production and R\&D. Second, the possibility that our model used to estimate discretionary accruals does not capture with efficiency all the necessary aspects to a robust estimation.

\section{AUTHOR INFORMATION}

Tarek Miloud is a Professor of Accounting and Finance at INSEEC Alpes-Savoie Business School. In his current position, Professor Tarek Miloud teaches courses in accounting, corporate finance and financial analysis. Before joining INSEEC Business School, he held professorial position at the Louvain School of Management, where he was assistant professor. His primary research areas of interest include corporate governance, earnings management, financial accounting, financial statement analysis; capital markets; and initial public offering. Professor Miloud is the author of several books and has published numerous articles in research publications. Professor Miloud received his Master of Finance degree from Alger University, and his M.B.A. and his Ph.D. in accounting/finance from the Louvain School of Management. E-mail: tmiloud@inseec.com

\section{REFERENCES}

1. Abdullah, I., Espenlaubb, S., \& Strongb, N. (2009). Earnings management around UK open offers. The European Journal of Finance, 15, 29-51.

2. Aharony, J., Lee, C., \& Wong, T. J. (2000). Financial packaging of IPO firms in China. Journal of Accounting Research, 38, 103-126. 
3. Alavi, A., Pham, P., \& Pham, T. (2008). Pre-IPO ownership structure and its impact on the IPO process. Journal of Banking and Finance, 32, 2361-2375.

4. Beaver, W. H., \& McNichols, M. F. (1998). The characteristic and Valuation of loss reserves of property casually insures. Review of Accounting Studies, 2, 73-95.

5. Beneish, M. (2001). Earnings management: A perspective. Managerial Finance, 27, 3-17.

6. Bessler, W., \& Thies, S. (2007). The long-run performance of initial public offerings in Germany. Managerial Finance, 33, 420-441.

7. Bhabra, H., \& Pettway, R. (2003). IPO prospectus information and subsequent performance. Financial Review, 38, 369-397.

8. Brav, A., \& Gompers, P. (1997). Myth or reality? The long-run underperformance of initial public offerings: evidence from venture and nonventure capital-backed companies. The Journal of Finance, 52, 1791-1821.

9. Brennan, M., \& Franks, J. (1997). Underpricing, ownership and control in initial public offerings of equity securities in the UK. Journal of Financial Economics, 45, 391-413.

10. Burgstaler, D., \& Dichev, I. (1997). Earnings management to avoid earnings decrease and losses. Journal of Accounting and Economics, 24, 99-126.

11. Bushee, B. (1998). The influence of institutional investors on myopic R\&D investment behavior. The Accounting Review, 73, 305-333.

12. Chen, G., Firth, M., Gao, D., \& Rui, O. (2006). Onwership structure, corporate governance, and fraud: evidence from China. Journal of Corporate Finance, 12, 424-448.

13. Chen, K., \& Yuan, H. (2004). Earnings management and capital resource allocation: Evidence from China's accounting-based regulation of rights issue. The Accounting Review, 74, 645-665.

14. Chou, D., Gombola, M., \& Liu, F. (2006). Earnings management and stock performace of reverse leveraged buyouts. Journal of Financial and Quantitative Analysis, 41, 407-438.

15. Clarkson, P., Dontoh, A., Richardson, G., \& Sefcik, E. (1992). The voluntary inclusion of earnings forecasts in IPO prospectuses. Contemporary Accounting Research, 8, 601-616.

16. Cormier, D., \& Martinez, I. (2006). Management earnings forecasts, discretionary accruals and stock market valuation: Evidence from French IPOs. The International Journal of Accounting, 41, 209-223.

17. Darrough, M., \& Rangan, S. (2005). Do Insiders manipulate earnings when they sell their shares in an initial public offering? Journal of Accounting Research, 43, 1-33.

18. Deangelo, L. (1986). Accounting numbers as market valuation substitutes: A study of management buyouts of public stockholders. The Accounting Review, 61, 400-420.

19. Dechow, P., Kothari, S. P., \& Watts, R. L. (1998). The relation between earnings and cash flows. Journal of Accounting and Economics, 25, 133-168.

20. Dechow, P., \& Skinner, D. (2000). Earnings management: Reconciling the views of accounting academics, practitioners, and regulators. Accounting Horizons, 14, 235-250.

21. Dechow, P., Sloan, R., \& Sweeney, P. (1995). Detecting earnings management. The Accounting Review, 70, 193-225.

22. Degeroge, F., Patel, J., \& Zeckhaiser, R. (1999). Earnings management to exceed thresholds. Journal of Business, 72, 1-33.

23. Dempsey, J., Hunt, H., \& Schroeder, N. (1993). Earnings management and corporate ownership structure: An examination of extraordinary item reporting. Journal of Business Finance \& Accounting, 20, 479-500.

24. DuCharme, L., Malatesta, P., \& Sefcik, E. (2004). Earnings management, stock issues, and shareholder lawsuits. Journal of Financial Economics, 71, 27-49.

25. Durtschi, C., \& Easton P. (2005). Earnings management? The shapes of the frequency distributions of earnings metrics are not evidence ipso facto. Journal of Accounting Research, 43, 521-556.

26. Eldenburg, L., Gunny, K., Hee, K., \& Sodersdtrom, N. (2011). Earnings management using real activities: Evidence from nonprofit hospitals. The Accounting Review, 86, 1605-1630.

27. Fama, E. (1998). Market efficiency, long-term returns, and behavioral finance. Journal of Financial Economics, 49, 283-306.

28. Fama, E., \& French, K. (1993). Common risk factors in the returns on stocks and bonds. Journal of Financial Economics, 33, 3-56.

29. Friedlan, J. M. (1994). Accounting choices of issuers of initial public offerings. Contemporary Accounting Research, 11, 1-31. 
30. Fudenberg, D., \& Tirole, J. (1995). A theory of income and dividend smoothing based on incumbency rents. Journal of Political Economy, 103, 440-455.

31. Gabrielsen, G., Gramlich, J., \& Plenborg, T. (2002). Managerial ownership, information content of earnings, and discretionary accruals in a non-US setting. Journal of Business Finance \& Accounting, 29, 967-988.

32. Grace, H., \& Koh, P. (2005). Presence of institutional investors influence accruals management? Evidence from Australia. Corporate Governance: An International Review, 13, 809-823.

33. Graham, J. R., Harvey, C. R., \& Rajgopal, S. (2005). The economic implications of corporate financial reporting. Journal of Accounting and Economics, 40, 3-73.

34. Guay, W., Kothari, S., \& Watts, R. L. (1996). A market-based evaluation of discretionary accruals model. Journal of Accounting Research, 34, 83-105.

35. Healy, P. (1985). The effect of bonus schemes on accounting decisions. Journal of Accounting and Economics, 7, 85-107.

36. Healy, P., \& Wahlen, J. M. (1999). A review of the earnings management literature and its implications for standard setting. Accounting Horizons, 13, 365-383.

37. Hensler, D. A., Rutherford, R. C., \& Springer, T. M. (1997). The survival of initial public offerings in the aftermarket. The Journal of Financial Research, 20, 93-110.

38. Herrmann, T., Inoue, T., \& Thomas, W. B. (2003). The sale of assets to manage earnings in Japan. Journal of Accounting Research, 41, 89-108.

39. Ibbotson, G., Sindelar, L., \& Ritter, R. (1988). Initial public offerings. Journal of Applied Corporate Finance, 1, 37-45.

40. Jain, A., \& Kini, O. (1994). The post-issue operating performance of IPO firms. The Journal of Finance, 49, 1699-1726.

41. Jain, B., \& Kini, O. (2000). Does the presence of venture capitalists improve the survival profile of IPO firms? Journal of Business Finance \& Accounting, 27, 1139-1183.

42. Janin, R. (2000). Accruals-based models for detecting earnings management and the French case. congrès 2000 - EAA, Munich.

43. Jones, J. (1991). Earnings management during import relief investigations. Journal of Accounting Research, 29, 193-228.

44. Koh, P. (2007). Institutional investor type, earnings management and benchmark beaters. Journal of Accounting and Public Policy, 26, 267-299.

45. Lambert, C., \& Sponem, S. (2005). Corporate governance and profit manipulation: A French field study. Critical Perspectives on Accounting, 16, 717-748.

46. Ljungqvist, A. (1997). The pricing of initial public offerings-Further evidence from Germany. European Economic Review, 41, 1309-1320.

47. Loughran, T., \& Ritter, J. (1997). The operating performance of firms conducting seasoned equity offerings. The Journal of Finance, 52, 1823-1850.

48. Lyon, J. D., Barber, B., \& Tsai, L. (1999). Improved methodology for tests of long-run abnormal stock returns. Journal of Finance, 54, 165-201.

49. Mchichols, M., \& Wilson, G. (1988). Evidence of earnings management from the provision for bad debts. Journal of Accounting and Economics, 26, 1-31.

50. Mitchell, M. L., \& Stafford, E. (2000). Managerial decisions and long-run stock price performance. Journal of Business, 73, 287-320.

51. Morck, R., Shleifer, A., \& Vishny, R. (1988). Management ownership and market valuation: An empirical analysis. Journal of Financial Economics, 20, 293-316.

52. Mulford, W., \& Comiskey, E. (2005). The Financial numbers game: Detecting creative accounting practices. Hoboken, NJ: John Wiley \& Sons, Inc.

53. Neill, J. D., Pourciau, S. G., \& Schaefer, T. F. (1995). Accounting method choice and IPO valuation. Accounting Horizons, 9, 68-80.

54. Peasnell, K., Pope, P., \& Young, S. (2000). Detecting earnings management using cross-sectional abnormal accruals models. Accounting and Business Research, 30, 313-326.

55. Perry, S. E., \& Williams, T. H. (1994). Earnings management preceding management buyout offers. Journal of Accounting Economics, 18, 157-179. 
56. Petroni, K. (1992). Optimistic reporting in the property-casualty insurance industry. Journal of Accounting and Economics, 15, 485-608.

57. Porter, M. (1992). Capital choices: Changing the way America invests in industry. Journal of Applied Corporate Finance, 5, 4-16.

58. Rangan, S. (1998). Earnings management and the performance of seasoned equity offerings. Journal of Financial Economics, 50, 101-122.

59. Ritter, J. (1991). The long run performance of initial public offerings. Journal of Finance, 46, 3-27.

60. Ritter, J., \& Welch, L. (2002). A review of IPO activity, pricing and allocations. Journal of Finance, 57, 1795-1828.

61. Roosenboom, P., van der Goot, T., \& Mertens, G. (2003). Earnings management and initial public offerings: evidence from the Netherlands. International Journal of Accounting, 38, 243-266.

62. Roychowdhury, S. (2006). Earnings management through real activities manipulation. Journal of Accounting and Economics, 42, 335-370.

63. Sánchez-Ballesta, J. P., \& García-Meca, E. (2007). Ownership structure, discretionary accruals and the informativeness of earnings. Corporate Governance: An International Review, 15, 677-691.

64. Schipper, K. (1989). Commentary on earnings management. Accounting Horizons, 3, 91-102.

65. Schrand, C., \& Zechman, S. (2012). Executive overconfidence and the slippery slope to financial misreporting. Journal of Accounting and Economics, 53, 311-329.

66. Scott, W. (2011). Financial accounting theory, $6^{\text {th }}$ Edition. Prentice Hall.

67. Shivakumar, L. (2000). Do firms mislead investors before seasoned equity offerings? Journal of Accounting Economics, 29, 339-371.

68. Teoh, S., Welch, I., \& Wong, T. J. (1998a). Earnings management and the long-run market performance of initial public offerings. Journal of Finance, 53, 1935-1974.

69. Teoh, S., Welch, I., \& Wong, T. J. (1998b). Earnings management and the underperformance of seasoned equity offering. Journal of Financial Economics, 50, 63-99.

70. Teoh, S., Wong, T. J., \& Rao, G. (1998c). Are accruals during initial public offering opportunistic? Review of Accounting Studies, 3, 175-208.

71. Thomas, J. K., \& Zhang, H. (2002). Inventory changes and future returns. Review of Accounting Studies, 7, 163-187.

72. Tirole, J. (2006). The theory of corporate finance. Princeton University Press.

73. Velury, U., \& Jenkins, D. (2006). Institutional ownership and the quality of earnings. Journal of Business Research, 59, 1043-1051.

74. Wahal, S., \& McConnell, J. (2000). Do institutional investors exacerbate managerial myopia? Journal of Corporate Finance, 6, 307-329.

75. Wang, D. (2006). Founding family ownership and earnings quality. Journal of Accounting Research, 44, 619-655.

76. Warfield, T., Wild, J., \& Wild, K. (1995). Managerial ownership, accounting choices, and informativeness of earnings. Journal of Accounting Economics, 20, 61-91.

77. Xie, H. (2001). The mispricing of abnormal accruals. The Accounting Review, 76, 737-373.

78. Yoon, S., \& Miller, G. (2002). Cash from operations and earnings management in Korea. The International Journal of Accounting, 37, 395-412. 